\title{
Evaluation of the cytocompatibility of methacrylate resin-based root canal sealers with osteoblast-like cells
}

\author{
Yadanar Su PHYO*, Kentaro HASHIMOTO*, Nobuyuki KAWASHIMA, Masashi KURAMOTO and Takashi OKIJI \\ Department of Pulp Biology and Endodontics, Division of Oral Health Sciences, Graduate School of Medical and Dental Sciences, Tokyo Medical \\ and Dental University (TMDU), Tokyo, Japan \\ Corresponding author, Nobuyuki KAWASHIMA; E-mail: kawashima.n.endo@tmd.ac.jp
}

\begin{abstract}
This study compared the cytocompatibilities of three methacrylate resin-based root canal sealers [MetaSEAL Soft (MSS), Hybrid Root SEAL (HRS), and Superbond Sealer (SBS)] in either freshly mixed or set conditions using the Kusa A1 osteoblastic cell line. The three sealers and an epoxy resin-based sealer (AH Plus; AHP) were extracted in culture medium; cell growth and osteogenic properties were analyzed. Cell adhesion on set sealers was analyzed with scanning electron microscopy. The respective extents of cell growth were as follows in freshly mixed and set sealer extracts: SBS $>$ MSS $>$ AHP $>$ HRS and SBS=AHP $>$ MSS $>$ HRS. Light irradiation of MSS and HRS increased the cell growth of set sealer extracts. Set SBS, MSS, and AHP did not alter expression of osteogenic genes or formation of mineralized nodules. Attached cells were observed only on SBS. In conclusion, the four sealers exhibited varying degrees of compatibility to osteoblasts; SBS and HRS were the most and least compatible, respectively.
\end{abstract}

Keywords: Cytocompatibility, Methacrylate resin-based root canal sealers, Osteoblasts, Scanning electron microscopy

\section{INTRODUCTION}

The primary objective of endodontic treatment is to eradicate intracanal pathogens and pathogenic substances. This is followed by hermetic sealing of the cleaned and shaped root canal space to prevent reinfection and entomb residual microorganisms ${ }^{1}$. Regardless of the root-filling technique, sealers are necessary to establish hermetic sealing by filling the space between the dentinal wall and the obturating core material ${ }^{2}$.

Available root canal sealers are currently composed of various formulations, including zinc oxide-eugenol, calcium hydroxide, silicone, calcium silicates, and several classes of resinous materials ${ }^{3)}$. However, none of the products are considered ideal; in particular, "traditional" sealers (e.g., zinc oxide-eugenol-based materials) show no or low adhesiveness to dentinal walls ${ }^{4}$. Because of advancements in dentin bonding technology, several methacrylate resin-based sealers have been developed in attempts to establish simultaneous bonding of root canal sealers to root-filling materials and dentin ${ }^{5)}$. Among these, Hybrid Root SEAL (HRS, also known as MetaSeal; Sun Medical, Moriyama, Japan) is a self-adhesive dual-curable sealer that contains 4-methacryloxyethyl trimellitate anhydride (4-META) as an adhesive monomer. MetaSEAL Soft (MSS; Sun Medical) is the next generation of Hybrid Root SEAL; it contains organic fillers to reduce the hardness of the set material, thereby improving removability if retreatment is necessary ${ }^{6}$. Superbond Sealer (SBS; Sun Medical) is a 4-META/methyl methacrylate-tri-n-butyl borane resin-

*These authors contributed equally to this work.

Color figures can be viewed in the online issue, which is available at J-STAGE.

Received Sep 9, 2020: Accepted Nov 9, 2020

doi:10.4012/dmj.2020-335 JOI JST.JSTAGE/dmj/2020-335 based sealer developed by modification of the SuperBond resin cement.

Root canal sealers extruded from apices during root canal filling procedures may exert harmful effects on periapical tissue. In particular, freshly mixed sealers may induce periapical inflammation ${ }^{7}$; if they are in contact with osteoblasts on the alveolar bone surface, freshly mixed sealers may demonstrate cytotoxicity that negatively influences the repair and healing process. Furthermore, some harmful components released from set sealers may prolong periapical inflammation ${ }^{8}$. However, research has been inconclusive regarding the cytocompatibilities of methacrylate resin-based root canal sealers; notably, the methacrylate polymer is considered to exhibit negligible cytotoxicity in the set condition, but causes moderate cytotoxicity early in the setting process ${ }^{9}$. HRS exhibits less cytotoxicity ${ }^{10)}$ and milder connective tissue reaction compared with a zinc oxide-eugenol sealer ${ }^{11)}$, but is more cytotoxic than $\mathrm{AH}$ Plus (AHP; Dentsply Sirona, Ballaigues, Switzerland), an epoxy resin-based sealer ${ }^{10)}$. Compared with other methacrylate resin-based sealers (e.g., EndoREZ and RealSeal/Epiphany), HRS is reportedly either less cytotoxic $^{12)}$ or induces more severe cytotoxicity ${ }^{13}$. SBS shows better cytocompatibility than methacrylate resinbased sealers ${ }^{14-16)}$ and $\mathrm{AHP}^{16)}$. Evidence concerning the biocompatibility of MSS is limited and conflicting; MSS has been reported to cause milder connective tissue reactions than AHP and a zinc oxide-eugenol sealer ${ }^{17}$, whereas it exhibits greater cytotoxicity than several other types of sealers ${ }^{17}$.

This study aimed to compare the cytocompatibility of MSS, HRS, and SBS in either freshly mixed or set conditions using the Kusa-A1 osteoblastic cell line. The 
null hypothesis was that there would be no difference in cytocompatibility among the three methacrylate resinbased sealers.

\section{MATERIALS AND METHODS}

\section{Cell culture and sample preparations}

Kusa-A1 cells ${ }^{18,19)}$ (an osteoblastic cell line derived from mouse osteogenic mesenchymal progenitor cells; Cell No: RCB2081; Cell Engineering Division, RIKEN BioResource Research Center, Ibaraki, Japan) were cultured in alpha-modified minimum essential medium ( $\alpha$-MEM, Wako Pure Chemical Industries, Osaka, Japan) containing $10 \%$ fetal bovine serum (Thermo Fisher Scientific, Waltham, MA, USA) at $37^{\circ} \mathrm{C}$ in $5 \%$ $\mathrm{CO}_{2}$. Culture medium was changed at 3-day intervals.

\section{Preparation of sealer extracts}

Three methacrylate resin-based sealers (i.e., MSS, HRS, and SBS) and an epoxy resin-based sealer (AHP) were used in this study (Table 1). The sealers were mixed aseptically in accordance with the manufacturers' instructions and placed in sterile cylindrical plastic rings (Ø $7 \mathrm{~mm}$ and height $3 \mathrm{~mm}$; $250 \mathrm{mg}$ per ring). They were immersed in $3 \mathrm{~mL}$ of $\alpha$-MEM immediately after filling in the rings (i.e., fresh samples) or following storage in a $\mathrm{CO}_{2}$ incubator $\left(5 \% \mathrm{CO}_{2}\right.$ and $95 \%$ air) at $37^{\circ} \mathrm{C}$ for $24 \mathrm{~h}$ to allow complete setting. The prepared samples were then shaken in $3 \mathrm{~mL}$ of $\alpha$-MEM at room temperature for 24 h (i.e., set groups without irradiation). Light irradiation was performed immediately after the injection of MSS and HRS into sterile cylindrical plastic rings (i.e., set samples). Light-irradiated samples of MSS and HRS [referred to as $\operatorname{MSS}(+)$ and $\operatorname{HRS}(+)$ ] were prepared by irradiating the sealers filled in the ring with an LED light curing unit (Blue Lex, Yoshida, Tokyo, Japan; 1,400 $\mathrm{mW} / \mathrm{cm}^{2}, 20 \mathrm{~s}$ ); they were then immersed in $\alpha$-MEM as described above. The media with sealers were shaken for $24 \mathrm{~h}$ at room temperature, sterilized with a syringe filter (pore size $0.45 \mu \mathrm{m}$, Sartorius, Göttingen, Germany), and used as sealer extracts for further experiments.

\section{Cell viability assay}

Kusa-A1 cells $\left(3 \times 10^{3}\right.$ cells/well) seeded in 96 -well plates were cultured with $100 \mu \mathrm{L} \alpha$-MEM for $24 \mathrm{~h}$, then cultured with sealer extracts for an additional $48 \mathrm{~h}$. Cells cultured with $\alpha$-MEM were used as control samples. Vital cell numbers were measured using the Cell Counting Kit-8 (CCK8; Dojindo Molecular Technologies, Kumamoto, Japan). Briefly, $10 \mu \mathrm{L}$ of CCK8 solution was added to the culture medium and the absorbance at $450 \mathrm{~nm}$ was measured with a spectrophotometer (TECAN Sunrise, Mannedorf, Switzerland), following $1 \mathrm{~h}$ of incubation at $37^{\circ} \mathrm{C}$.

\section{Osteoblastic marker expression}

Kusa-A1 cells $\left(5 \times 10^{4}\right.$ cells/well) were seeded in 24 -well dishes and cultured with eightfold diluted set samples (MSS without light irradiation, HRS without light irradiation, SBS, and AHP) or $\alpha$-MEM (control) for 72 h. Total RNA was extracted using an ultra-thin polymer membrane (QuickGene, Kurabo, Osaka, Japan), and cDNA was synthesized (PrimeScript RT reagent Kit: Perfect Real Time, Takara Bio, Shiga, Japan) from extracted RNA (150 ng). Real-time polymerase chain reaction was performed with Taq polymerase mixture including SYBR Green (GoTaq qPCR Master Mix, Promega, Madison, WI, USA), synthesized cDNA, and specific primers for osteoblasts using a real-time thermal cycler (CFX96, Bio-Rad, Hercules, CA, USA). PCR reactions were performed using 2-step cycling profiles $\left(40\right.$ cycles) with $15 \mathrm{~s}$ denaturation $\left(95^{\circ} \mathrm{C}\right)$ and $60 \mathrm{~s}$ annealing $\left(60^{\circ} \mathrm{C}\right)$ per cycle following 2 min denaturation $\left(95^{\circ} \mathrm{C}\right)$. Beta-actin was used as an internal control. The primer sequences were as follows: alkaline phosphatase (Alp; accession number NM_007431), anti-sense: 5'GGAATGTAGTTCTGCTCATGGAC-3' and sense: 5'-GATTACGCTCACAACAACTACCAG-3'; integrin

Table 1 Root canal sealers used in this study

\begin{tabular}{|c|c|c|c|}
\hline Material & Manufacturer & Lot No. & Composition \\
\hline $\begin{array}{l}\text { MetaSEAL } \\
\text { Soft }\end{array}$ & $\begin{array}{l}\text { Sun Medical, } \\
\text { Moriyama, } \\
\text { Japan }\end{array}$ & $\begin{array}{l}\text { Liquid: TW1 } \\
\text { Powder: VF } 1\end{array}$ & $\begin{array}{l}\text { Liquid: 4-META, HEMA, di-methacrylates, photoinitiator, water } \\
\text { Powder: bismuth carbonate oxide, organic filler, aromatic amine }\end{array}$ \\
\hline $\begin{array}{l}\text { Hybrid Root } \\
\text { SEAL }\end{array}$ & Sun Medical & $\begin{array}{l}\text { Liquid: VG } 11 \\
\text { Powder: TX } 12\end{array}$ & $\begin{array}{l}\text { Liquid: 4-META, HEMA, di-methacrylates, photoinitiator } \\
\text { Powder: zirconium oxide, amorphous silica, aromatic amine }\end{array}$ \\
\hline $\begin{array}{l}\text { Superbond } \\
\text { Sealer }\end{array}$ & Sun Medical & $\begin{array}{l}\text { Liquid: TE } 2 \\
\text { Powder: TM } 1 \\
\text { Catalyst: SW } 33\end{array}$ & $\begin{array}{l}\text { Liquid: 4-META, MMA } \\
\text { Powder: zirconium oxide }(80 \% / w), \text { PMMA }(20 \% / w) \\
\text { Catalyst: TBB-O }\end{array}$ \\
\hline AH Plus & $\begin{array}{l}\text { Dentsply Sirona, } \\
\text { Ballaigues, } \\
\text { Switzerland }\end{array}$ & 1911001017 & $\begin{array}{l}\text { Paste A: bisphenol A epoxy resin, bisphenol F epoxy resin, } \\
\text { calcium tungstate, zirconium oxide, silica, iron oxide pigments } \\
\text { Paste B: dibenzyldiamine, aminoadamantane, tricyclodecane- } \\
\text { diamine, calcium tungstate, zirconium oxide, silicone oil, silica }\end{array}$ \\
\hline
\end{tabular}

4-META: 4-methacryloxyethyl trimellitate anhydride, HEMA: 2-hydroxyethyl methacrylate, MMA: methyl methacrylate, PMMA: polymethyl methacrylate, TBB-O: partially oxidized tri-n-butylborane 
binding sialoprotein (Ibsp; accession number NM_008318), anti-sense: 5'-AGTAATAATTCTGACCCTCGTAGCC-3' and sense: 5'-TATGAAGTCTATGACAACGAGAACG-3'; $\beta$-actin (accession number NM_ 007393), anti-sense: 5'GTAAAGACCTCTATGCCAACACAGT-3' and sense: 5'AATGATCTTGATCTTCATGGTGCTA-3'

\section{Mineralized nodule formation}

Kusa-A1 cells $\left(2 \times 10^{4}\right.$ cells/well) were seeded in 48 -well plates and cultured in $\alpha$-MEM containing $10 \%$ fetal bovine serum. After $24 \mathrm{~h}$ of culture, the medium was changed to an osteoinduction medium containing L-ascorbic acid (0.2 mM; Wako Pure Chemical Industries) and $\beta$-glycerophosphate (5.0 mM; Sigma Aldrich, St. Louis, MO, USA), with or without eightfold diluted sealer extracts. Mineralized nodules were stained with alizarin red S (Wako Pure Chemical Industries) after 10 days of culture. The mineralized nodule area was measured with ImageJ2 software (https://imagej.net/ImageJ2).

\section{Scanning electron microscopy}

Set sealers filled in the ring were rinsed with phosphatebuffered saline and placed in 48-well plates; Kusa-A1 cells $\left(2 \times 10^{4}\right.$ cells/well) were then seeded and cultured on the samples for 3 days. Following fixation with $2.5 \%$ glutaraldehyde (Wako Pure Chemical Industries), the specimens were dehydrated using a graded ethanol series, dried in a critical-point dryer (HCP 2, Hitachi, Tokyo, Japan), sputter-coated with platinum using an ion-coater (E102, Hitachi), and examined with a scanning electron microscope (Hitachi S-4500) at an accelerating voltage of $5 \mathrm{kV}$.

\section{Statistical analysis}

Data regarding cell viability and osteoblastic marker expression were compared among groups using oneway analysis of variance and Tukey post hoc test. Data regarding mineralized nodule formation were compared among groups using one-way analysis of variance and Dunnett's post hoc test. All statistical analyses were performed using statistical software (GraphPad Prism v8.1, GraphPad, San Diego, CA, USA), and $p$-values $<0.05$ were considered to be statistically significant.

\section{RESULTS}

\section{Cell viability}

Figure 1 shows the viabilities of Kusa-A1 cells after exposure to fresh samples. Cells exposed to MSS and MSS(+) exhibited significant reductions in viability, compared with the control, at dilutions up to $1 / 8$ and $1 / 2$, respectively $(p<0.05)$; they exhibited viabilities comparable with the control at dilutions of 1/32 and $1 / 8$, respectively. Cells exposed to $\operatorname{MSS}(+)$ exhibited significantly greater viabilities than cells exposed to MSS in comparisons of extracts with the same dilution $(p<0.05)$. For HRS and HRS $(+)$, cell viabilities were below the limit of detection. For cells exposed to SBS, the viable cell count was comparable with the control at $1 / 2$ dilution, whereas it was significantly higher than the control at dilutions of $1 / 8$ and $1 / 32(p<0.05)$. Cells exposed to AHP exhibited significant reduction in viability, compared with the control, at dilutions up to $1 / 32(p<0.05)$.

Figure 2 shows the viabilities of Kusa-A1 cells after exposure to set samples. Cells exposed to MSS and MSS(+) exhibited significant reductions in viability, compared with the control, at dilutions up to $1 / 8(p<0.05)$; cells exposed to $\mathrm{MSS}(+)$ exhibited significantly greater

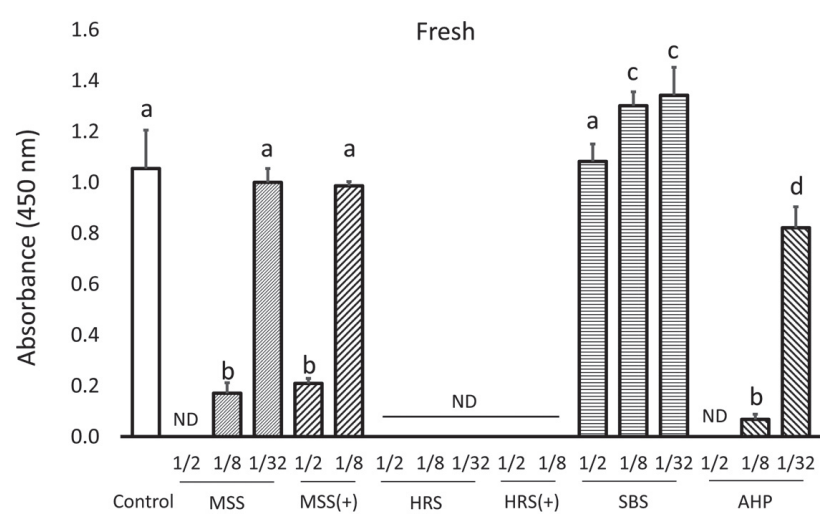

Fig. 1 Viability of Kusa-A1 cells cultured with diluted extracts of freshly-mixed sealers.

Cells were cultured with diluted extracts of fresh samples with or without light irradiation, and cell viability was measured at $72 \mathrm{~h}$ with CCK8. Dilution ratio is indicated as fractions. Different letters indicate significant differences between groups $(n=4, p<0.05)$. MSS, MetaSEAL Soft; HRS, Hybrid Root SEAL; SBS, Superbond Sealer; and AHP, AH Plus. (+), light-irradiated. ND, not detected.



Fig. 2 Viability of Kusa-A1 cells cultured with diluted extracts of set sealers.

Cells were cultured with diluted extracts of set samples with or without light irradiation, and cell viability was measured at $72 \mathrm{~h}$ with CCK8. Dilution ratio is indicated as fractions. Different letters indicate significant differences between groups $(n=4, p<0.05)$. MSS, MetaSEAL Soft; HRS, Hybrid Root SEAL; SBS, Superbond Sealer; and AHP, AH Plus. (+), light-irradiated. ND, not detected. 
viabilities than MSS in comparisons of extracts with the same dilution $(p<0.05)$. Cells exposed to HRS and HRS $(+)$ also showed significant reductions in viability, compared with the control $(p<0.05)$; cells exposed to MSS showed a significant reduction in viability, compared with $\operatorname{MSS}(+)$, in extracts with the same dilution $(p<0.05)$. Cells exposed to SBS and AHP did not show significant differences in viability, compared with the control $(p>0.05)$.

\section{Osteogenic marker expression}

As shown in Fig. 3, exposure to eightfold diluted set MSS, SBS, and AHP extracts induced the expression of Alp and Ibsp in Kusa-A1 cells at levels similar to the control, with no significant differences among test extracts $(p>0.05)$. No expression of Alp or Ibsp mRNA
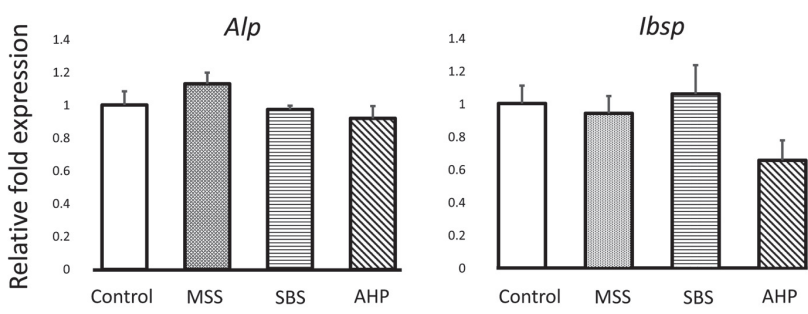

Fig. 3 Osteogenic marker expression in Kusa-A1 cells cultured with diluted extracts of set sealers. Cells were cultured with 8 -fold diluted extracts of set samples, and Alp and Ibsp mRNA expression was measured at $72 \mathrm{~h}$ by real-time PCR using specific primers. There were no significant differences among groups $(n=4, p>0.05)$. MSS, MetaSEAL Soft; HRS, Hybrid Root SEAL; SBS, Superbond Sealer; and AHP, AH Plus. Hybrid Root SEAL is not indicated in this graph because RNA extraction was not possible because of the limited number of vital cells. was detected in Kusa-A1 cells cultured with eightfold diluted set HRS extracts.

\section{Mineralized nodule formation}

As shown in Fig. 4, exposure to all eightfold diluted set sealer extracts induced mineralized nodule formation in Kusa-A1 cells. Cells exposed to HRS exhibited

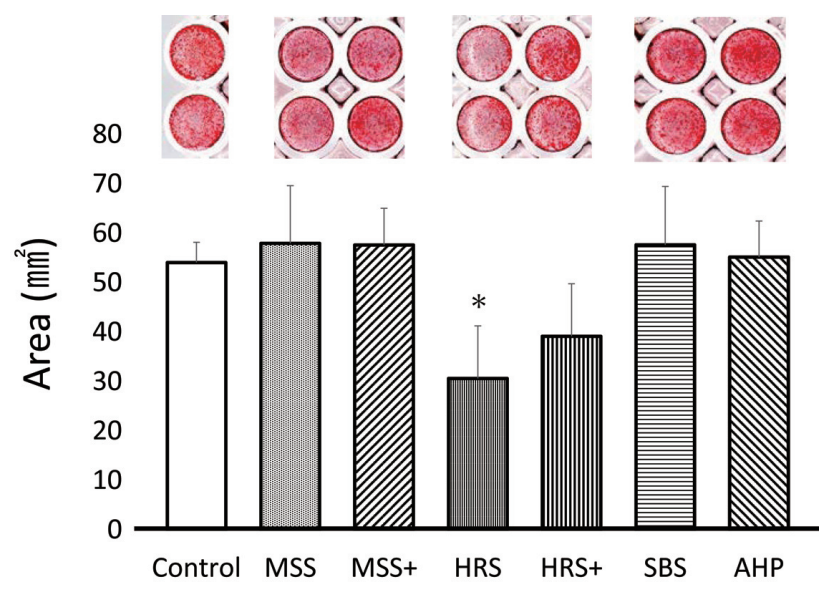

Fig. 4 Mineralized nodule formation in Kusa-A1 cells cultured with diluted extracts of set sealers.

Cells were cultured in the osteoinducing medium with 8-fold diluted extracts of set samples for 10 days and mineralized nodules were stained with alizarin-red staining solution. Stained nodules were quantified by ImageJ2 software. An asterisk mark indicates significant difference compared with control $(n=4, p<0.05)$. Images above each bar in the graph show two representative alizarin-redstained cultures of the corresponding group. MSS, MetaSEAL Soft; HRS, Hybrid Root SEAL; SBS, Superbond Sealer; and AHP, AH Plus.
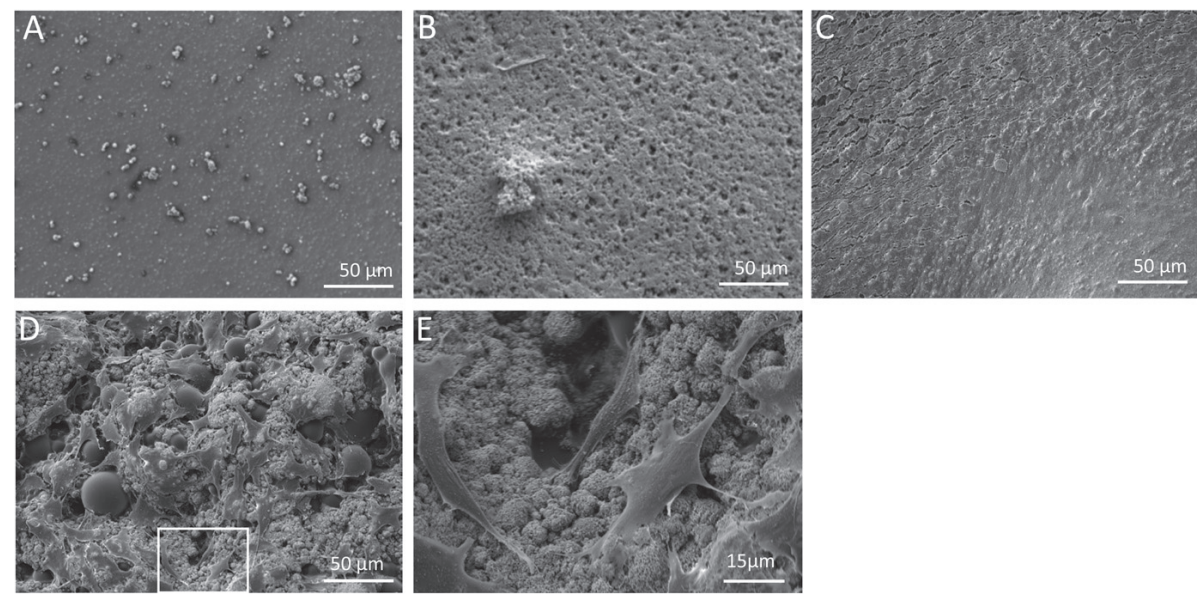

Fig. 5 Scanning electron microscopic observation of Kusa-A1 cells attached on the surface of set sealers.

Kusa-A1 cells were cultured on set MetaSEAL Soft (A), Hybrid Root SEAL (B), AH Plus (C), and Superbond Sealer (D, E) for 3 days. (E) Higher magnification view of the boxed area in $\mathrm{D}$. 
significantly less mineralized nodule formation than the control $(p<0.05)$.

\section{Cell attachment}

Survival and attachment to sealers was not observed among cells exposed to MSS, HRS, or AHP (Figs. 5A-C). In contrast, substantial populations of well-spread, attached cells with numerous filopodia or pseudopodia were observed upon exposure to SBS (Figs. 5D, E).

\section{DISCUSSION}

This study demonstrated that exposure to MSS or HRS significantly reduced the viability of Kusa-A1 cells. The toxic effects of MSS and HRS were also clearly observed in scanning electron microscopy analysis where KusaA1 cells did not remain adhered during exposure to MSS or HRS. Notably, cells exposed to SBS showed significantly greater viability than cells exposed to MSS and HRS; cells cultured on SBS exhibited a well-spread shape with numerous cytoplasmic processes that may be associated with cell adhesion. Thus, the null hypothesis that cytocompatibility would not differ among the three methacrylate resin-based sealers was rejected.

The cytotoxicities of resin-based materials are primarily attributable to residual monomers released from these sealers ${ }^{20,21)}$. Among the constituents of the presently examined sealers, 2-hydroxyethyl methacrylate (HEMA) contained in MSS and HRS may be associated with the lower cytocompatibilities of these sealers, because HEMA is able to penetrate into the cell wall and cause cellular damage at low concentrations ${ }^{22,23)}$. A high concentration of HEMA (4 mg/mL medium) inhibits intracellular tyrosine phosphorylation, which is an important signal transduction messenger, in L929 fibroblasts ${ }^{24)}$. Cell growth inhibition and cell cycle perturbation are also induced by HEMA in human gingival epithelial cells and dental pulp cells ${ }^{25)}$. Furthermore, depletion of glutathione (an index of oxidative stress) and production of reactive oxygen species are both induced by $\mathrm{HEMA}^{25)}$. Notably, dimethacrylates, such as bisphenol A glycerolate dimethacrylate, urethane-dimethacrylate, and triethylene glycol dimethacrylate, have been reported to show higher cytotoxicity to human gingival fibroblasts, compared with $\mathrm{HEMA}^{26)}$, suggesting that dimethacrylates are also associated with the lower cytocompatibilities of HRS and MSS. Triacrylate, which is contained only in HRS, may also be associated with the inferior cytocompatibility of HRS compared with MSS, because triacrylate-derived acrylic acid exhibits greater toxicity than methyl methacrylate ${ }^{27)}$.

Light irradiation improved the cytocompatibilities of MSS and HRS, supporting the notion that the cytotoxicities of light-cured resin-based materials are inversely proportional to the light-curing time, which enhances the rate of monomer conversion ${ }^{28}$. Thus, the severe cytotoxicity of HRS suggests a lower monomer conversion rate in this material, even when it has been light-cured. From a clinical perspective, light curing of dual-curable resin sealers primarily tends to polymerize the coronal portion for early establishment of a tight coronal seal ${ }^{29)}$; it presumably shows limited effects in the apical portion because of restricted access for the curing light.

In this study, SBS exhibited the most prominent cytocompatibility. 4-META, the main functional monomer of the three sealers examined, has been reported to show mid-range cytotoxicity among monomethacrylates with functional groups ${ }^{27)}$. However, 4-META appears to be well tolerated, because SBS did not interfere with Kusa-A1 cell viability. This finding is consistent with the results of an earlier report, in which 4-META showed lower cytotoxicity to human dental pulp cells ${ }^{30)}$. Methyl methacrylate, the major component of SBS, reportedly less cytotoxic than many other resin monomers ${ }^{27,31)}$. Tributyl borane, a polymerization initiator, may reduce the amounts of residual monomers and free radical synthesis after polymerization ${ }^{32}$. The present findings are also consistent with the results of an earlier study, in which a 4-META/methyl methacrylatetri-n-butyl borane resin was found to be minimally cytotoxic to osteoblastic cells except during the early curing stage ${ }^{33)}$. This study also revealed that fresh and diluted SBS promoted the cell growth. SBS is reported to release boron ${ }^{34)}$, which stimulates cell growth in low concentrations $(0.1-0.5 \mathrm{mM})$ via activation of mitogenactivated protein kinase pathways ${ }^{35}$. Moreover, boron at physiological concentration induces lymphocyte proliferation $^{36}$ ) probably through its antioxidant potential $^{37)}$. Accordingly, boron released from SBS may be involved in the promoted cell growth induced by fresh and diluted SBS samples.

In this study, the cytotoxicities of three methacrylate resin-based sealers were compared with the cytotoxicity of AHP, which is one of the most widely evaluated sealers ${ }^{38)}$. Fresh AHP showed substantial cytotoxicity, which is consistent with the results of previous investigations; this might be due to the release of unpolymerized epoxy resin monomers ${ }^{39,40)}$. AHP is reportedly formaldehyde-free, which represents an improvement from its predecessor, AH26; however, AHP has been found to release a small amount of formaldehyde during the setting process ${ }^{39)}$, which might be responsible for the observed cytotoxicity of fresh AHP extracts. In contrast, set AHP showed minimal cytotoxicity to Kusa-A1 cells. Similarly, several earlier studies showed that set AHP was minimally cytotoxic $^{14,39,40)}$, although one study showed that set AHP severely interfered with cell viability ${ }^{16)}$.

mRNA expression levels of Alp and Ibsp in Kusa-A1 cells were not disturbed by exposure to eightfold diluted set sealer samples, with the exception of HRS. This agreed with the results of our cell growth experiments and with prior findings that HRS diluent induces downregulation of Alp and Ibsp mRNA expression in cementoblasts $^{13,41)}$. Mineralized nodule formation was also significantly disturbed in cells exposed to eightfold diluted set HRS, although the formation was confirmed. To induce mineralized nodule formation, standard 
culture medium was changed to osteoinduction medium containing sealer samples after detection of confluency. Thus, mineralized nodule formation was induced in the remaining viable cells, although further cell growth may have inhibited in the presence of HRS samples. Cells exposed to eightfold diluted set MSS showed slight inhibition of growth, but did not exhibit disturbed osteogenic gene expression or mineralized nodule formation, suggesting minimal harmful effects of MSS on the osteogenic potential of osteoblasts.

Scanning electron microscopy images of cell culture experiments revealed that attached cells were only observed upon exposure to SBS; Kusa-A1 cells cultured in the presence of SBS appeared to be elongated and possess multiple cytoplasmic extensions that projected from the cells to the surrounding surface (Fig. 5D, E). These results may be attributed to various factors such as chemical composition, particle size, surface topography, and sample bioactivity. No attached cells were found upon exposure to MSS, HRS, or AHP, although cells exposed to set AHP extract did not demonstrate significant reductions of viability (Fig. 2). Cells placed on the samples may have been directly affected by non-diluted toxic components released from the samples. Moreover, AHP diluents have been reported to disturb mRNA expression of collagen type $\mathrm{I}^{41)}$, a major component of extracellular matrix that is essential for cell attachment ${ }^{42}$. Therefore, disturbance of extracellular matrix synthesis (e.g., through disruption of collagen type I mRNA expression) may have occurred in Kusa-A1 cells cultured on set sealers except SBS, which may have led to the absence of cell attachment upon exposure to MSS, HRS, or AHP.

\section{CONCLUSION}

Our findings indicate that MSS, HRS, SBS, and AHP exhibited varying degrees of cytocompatibility with Kusa-A1 osteoblasts, such that SBS and HRS were the most and least compatible, respectively.

\section{ACKNOWLEDGMENTS}

The authors have no conflicts of interest related to this study. The authors thank Ryan ChastainGross, Ph.D., from Edanz Group (https://en-authorservices.edanzgroup.com/ac) for editing a draft of this manuscript.

\section{REFERENCES}

1) Johnson W, Kulild JC, Tay F. Obturation of the cleaned and shaped root canal system. In: Hargreaves KM, Berman LH, editors. Cohen's Pathway of the Pulp. 11th ed. St. Louis, MO: Elsevier; 2016. p. 280-322.

2) Skinner RL, Himel VT. The sealing ability of injection-molded thermoplasticized gutta-percha with and without the use of sealers. J Endod 1987; 13: 315-317.

3) Komabayashi T, Colmenar D, Cvach N, Bhat A, Primus C, Imai Y. Comprehensive review of current endodontic sealers. Dent Mater J 2020; 39: 703-720.
4) Lee KW, Williams MC, Camps JJ, Pashley DH. Adhesion of endodontic sealers to dentin and gutta-percha. J Endod 2002; 28: 684-688.

5) Kim YK, Grandini S, Ames JM, Gu LS, Kim SK, Pashley DH, et al. Critical review on methacrylate resin-based root canal sealers. J Endod 2010; 36: 383-399.

6) Edanami N, Shigetani Y, Yoshiba K, Hinata G, Yoshiba N, Okiji T. Evaluation of the biocompatibility of a 4-METAcontaining resin-based root canal sealer in rat subcutaneous tissue. Jpn J Conserv Dent 2016; 59: 65-73.

7) Geurtsen W. Biocompatibility of root canal filling materials. Aust Endod J 2001; 27: 12-21.

8) Tepel J, Darwisch el Sawaf M, Hoppe W. Reaction of inflamed periapical tissue to intracanal medicaments and root canal sealers. Endod Dent Traumatol 1994; 10: 233-238.

9) Hirabayashi C, Imai Y. Studies on MMA-TBB resin. I. Comparison of TBB and other initiators in the polymerization of PMMA/MMA resin. Dent Mater J 2002; 21: 314-321.

10) Pinna L, Brackett MG, Lockwood PE, Huffman BP, Mai S, Cotti E, et al. In vitro cytotoxicity evaluation of a self-adhesive, methacrylate resin-based root canal sealer. J Endod 2008; 34: 1085-1088.

11) Yamanaka Y, Shigetani Y, Yoshiba K, Yoshiba N, Okiji T. Immunohistochemical analysis of subcutaneous tissue reactions to methacrylate resin-based root canal sealers. Int Endod J 2011; 44: 669-675.

12) Ames JM, Loushine RJ, Babb BR, Bryan TE, Lockwood PE, Sui $\mathrm{M}$, et al. Contemporary methacrylate resin-based root canal sealers exhibit different degrees of ex vivo cytotoxicity when cured in their self-cured mode. J Endod 2009; 35: 225228.

13) Al-Hiyasat AS, Tayyar M, Darmani H. Cytotoxicity evaluation of various resin based root canal sealers. Int Endod J 2010; 43: 148-153.

14) Eldeniz AU, Mustafa K, Ørstavik D, Dahl JE. Cytotoxicity of new resin-, calcium hydroxide- and silicone-based root canal sealers on fibroblasts derived from human gingiva and L929 cell lines. Int Endod J 2007; 40: 329-337.

15) Maeda H, Tomokiyo A, Koori K, Monnouchi S, Fujii S, Wada $\mathrm{N}$, et al. An in vitro evaluation of two resin-based sealers on proliferation and differentiation of human periodontal ligament cells. Int Endod J 2011; 44: 425-431.

16) Garza EG, Wadajkar A, Ahn C, Zhu Q, Opperman LA, Bellinger LL, et al. Cytotoxicity evaluation of methacrylatebased resins for clinical endodontics in vitro. J Oral Sci 2012; 54: 213-217.

17) Szczurko G, Pawinska M, Luczaj-Cepowicz E, Kierklo A, Marczuk-Kolada G, Holownia A. Effect of root canal sealers on human periodontal ligament fibroblast viability: ex vivo study. Odontology 2018; 106: 245-256.

18) Umezawa A, Maruyama T, Segawa K, Shadduck RK, Waheed A, Hata J. Multipotent marrow stromal cell line is able to induce hematopoiesis in vivo. J Cell Physiol 1992; 151: 197205.

19) Kawashima N, Shindo K, Sakamoto K, Kondo H, Umezawa A, Kasugai S, et al. Molecular and cell biological properties of mouse osteogenic mesenchymal progenitor cells, Kusa. J Bone Miner Metab 2005; 23: 123-133.

20) Kurt A, Altintas SH, Kiziltas MV, Tekkeli SE, Guler EM, Kocyigit A, et al. Evaluation of residual monomer release and toxicity of self-adhesive resin cements. Dent Mater J 2018; 37: 40-48.

21) Moharamzadeh K, Van Noort R, Brook IM, Scutt AM. Cytotoxicity of resin monomers on human gingival fibroblasts and HaCaT keratinocytes. Dent Mater 2007; 23: 40-44.

22) Gallorini M, Cataldi A, di Giacomo V. HEMA-induced cytotoxicity: oxidative stress, genotoxicity and apoptosis. Int Endod J 2014; 47: 813-818.

23) Bouillaguet S, Wataha JC, Hanks CT, Ciucchi B, Holz J. In 
vitro cytotoxicity and dentin permeability of HEMA. J Endod 1996; 22: 244-248.

24) Kaga M, Noda M, Ferracane JL, Nakamura W, Oguchi H, Sano H. The in vitro cytotoxicity of eluates from dentin bonding resins and their effect on tyrosine phosphorylation of L929 cells. Dent Mater 2001; 17: 333-339.

25) Chang HH, Guo MK, Kasten FH, Chang MC, Huang GF, Wang YL, et al. Stimulation of glutathione depletion, ROS production and cell cycle arrest of dental pulp cells and gingival epithelial cells by HEMA. Biomaterials 2005; 26: 745-753.

26) Reichl FX, Esters M, Simon S, Seiss M, Kehe K, Kleinsasser $\mathrm{N}$, et al. Cell death effects of resin-based dental material compounds and mercurials in human gingival fibroblasts. Arch Toxicol 2006; 80: 370-377.

27) Yoshii E. Cytotoxic effects of acrylates and methacrylates: relationships of monomer structures and cytotoxicity. J Biomed Mater Res 1997; 37: 517-524.

28) Costa CA, Oliveira MF, Giro EM, Hebling J. Biocompatibility of resin-based materials used as pulp-capping agents. Int Endod J 2003; 36: 831-839.

29) Nagas E, Uyanik MO, Sahin C, Durmaz V, Cehreli ZC. Effects of different light-curing units and obturation techniques on the seal of the Resilon/Epiphany system. J Endod 2008; 34: 1230-1232.

30) Fujisawa S, Atsumi T. Cytotoxicities of a 4-META/MMATBBO resin against human pulp fibroblasts. Dent Mater J 2004; 23: 106-108.

31) Taira Y, Imai Y. Review of methyl methacrylate (MMA)/ tributylborane (TBB)-initiated resin adhesive to dentin. Dent Mater J 2014; 33: 291-304.

32) Nakagawa K, Saita M, Ikeda T, Hirota M, Park W, Lee MC, et al. Biocompatibility of 4-META/MMA-TBB resin used as a dental luting agent. J Prosthet Dent 2015; 114: 114-121.

33) Morotomi T, Hirata-Tsuchiya S, Washio A, Kitamura C.
Effects of 4-META/MMA-TBB resin at different curing stages on osteoblasts and gingival epithelial cells. J Adhes Dent 2016; 18: 111-118.

34) Kawasaki A, Hayashi Y, Yanagiguchi K, Yamada S, Syudo M, Igawa $\mathrm{K}$, et al. Effects of eluted components from 4-META/ MMA-TBB adhesive resin sealers on osteoblastic proliferation. J Dent Sci 2012; 7: 94-98.

35) Park M, Li Q, Shcheynikov N, Zeng W, Muallem S. NaBC1 is a ubiquitous electrogenic $\mathrm{Na}^{+}$-coupled borate transporter essential for cellular boron homeostasis and cell growth and proliferation. Mol Cell 2004; 16: 331-341.

36) Routray I, Ali S. Boron induces lymphocyte proliferation and modulates the priming effects of lipoposaccharide on macrophages. PLoS One 2016; 11: e0150607.

37) Gougerot-Pocidalo MA, Fay M, Roche Y, Chollet-Martin S. Mechanisms by which oxidative injury inhibits the proliferative response of human lymphocytes to PHA. Effect of the thiol compound 2-mercaptoethanol. Immunology 1988; 64: 281-288.

38) Schäfer E, Bering N, Bürklein S. Selected physicochemical properties of AH Plus, EndoREZ and RealSeal SE root canal sealers. Odontology 2015; 103: 61-65.

39) Leyhausen G, Heil J, Reifferscheid G, Waldmann P, Geurtsen W. Genotoxicity and cytotoxicity of the epoxy resin-based root canal sealer AH plus. J Endod 1999; 25: 109-113.

40) Jung S, Sielker S, Hanisch MR, Libricht V, Schäfer E, Dammaschke T. Cytotoxic effects of four different root canal sealers on human osteoblasts. PLoS One 2018; 13: e0194467.

41) Hakki SS, Bozkurt BS, Ozcopur B, Gandolfi MG, Prati C, Belli S. The response of cementoblasts to calcium phosphate resin-based and calcium silicate-based commercial sealers. Int Endod J 2013; 46: 242-252.

42) Frantz C, Stewart KM, Weaver VM. The extracellular matrix at a glance. J Cell Sci 2010; 123: 4195-4200. 